DOI: $10.19195 / 0524-4544.327 .8$

\author{
MARIUSZ KOTULSKI \\ ORCID: 0000-0002-4957-2363 \\ Uniwersytet Jagielloński \\ mariusz.kotulski@uj.edu.pl
}

\title{
Samorząd terytorialny w dwudziestoleciu międzywojennym
}

\begin{abstract}
Abstrakt: Wśród wyzwań odradzającego się w 1918 roku państwa polskiego była także budowa własnej struktury administracji publicznej. Przejmując po państwach zaborczych odmienne modele administracji oraz samorządu terytorialnego (o zróżnicowanej budowie i stopniu rozwoju), celowe było przyjęcie ewolucyjnej metody kreowania jego struktury organizacyjnej. Oparto się więc na dotychczasowych strukturach, znanych miejscowej ludności, modyfikując je tylko w kierunku demokratyzacji, niwelacji różnic i osiągnięcia pewnych pożądanych standardów. Stąd też wyróżnić można dwa podstawowe etapy w budowie samorządu terytorialnego II Rzeczypospolitej: pierwszy — do wejścia w życie ustawy scaleniowej i drugi — późniejszy. I choć ustawę scalającą z 1933 roku należy ocenić pozytywnie, jako krok pozwalający na ujednolicenie w skali państwa struktury samorządu terytorialnego na szczeblu gminy i powiatu, to nie była ona wolna od wad. Nie udało się także w pełni utworzyć struktur samorządu terytorialnego na szczeblu wojewódzkim. Wynikało to po części z braku spójnej koncepcji funkcjonowania samorządu terytorialnego, jego miejsca w administracji publicznej i roli w państwie. Dążenie po 1926 roku do centralizacji aparatu państwowego widoczne było nie tylko w zmianach ustawowych, ale także w lakonicznych regulacjach konstytucji kwietniowej dotyczących samorządu terytorialnego. Jednak w pełni należy docenić wysiłek zmierzający do zniwelowania rozbieżności prawnych i stojących za nimi różnic ekonomicznych, kulturowych, populacyjnych i narodowościowych włożony w ujednolicanie i budowę struktur samorządu terytorialnego w latach 1918-1939. Na wspomnienie zasługuje także znaczący dorobek polskiej doktryny okresu międzywojennego w badaniu samorządu terytorialnego oraz rozwój czasopism poświęconych tej tematyce.
\end{abstract}

Słowa kluczowe: samorząd terytorialny, dwudziestolecie międzywojenne, II Rzeczpospolita.

Przypadająca w tym roku setna rocznica odzyskania przez Polskę niepodległości skłania do refleksji nie tylko nad wydarzeniami historycznymi, które do tego doprowadziły, ale także nad podjętą wówczas pracą w umacnianiu bytu pań- 
stwowego, budowaniem zrębów struktury administracyjnej, jej kształtowaniem i ujednolicaniem w latach późniejszych. $Z$ dzisiejszego punktu widzenia i w kontekście naszych doświadczeń w tworzeniu współczesnej administracji publicznej oraz rozlicznych dyskusji nad jej funkcjonowaniem widoczne jest, jak wielki był to wysiłek i z jakimi wiązało się to trudnościami. Dotyczyło to także istnienia i zasad funkcjonowania samorządu terytorialnego w odrodzonej Polsce.

\section{Geneza}

Początków nowoczesnego samorządu terytorialnego zwykło się doszukiwać w okresie Wielkiej Rewolucji Francuskiej. Wówczas to, na podstawie teorii tzw. naturalnych praw gminy - pouvoir municipal, powołana w lipcu 1789 roku Konstytuanta przyjęła ustawę z 14 grudnia 1789 roku o gminach. Akt ten ujednolicił ustrój gmin ${ }^{1}$, rozróżnił organy stanowiące i wykonawcze oraz ustanowił demokratyczną zasadę wybieralności organów samorządowych ${ }^{2}$. Co ciekawe, wskazywał on na samorząd jako na czwartą władzę (po ustawodawczej, wykonawczej oraz sądowniczej). Także uchwalona dwa lata później pierwsza konstytucja republikańska z 1791 roku określała samorząd mianem „władzy komunalnej”3.

Pod wpływem tych idei uchwalona została w Polsce Ustawa z 18 kwietnia 1791 roku Miasta nasze królewskie wolne w państwach Rzeczypospolitej. W art. 1 pkt 12 tej ustawy stwierdzono, iż „obieranie przez obywatelów miast własnego magistratu, mianowicie burmistrzów, wójtów i wszelkich urzędników, jako jest cechą wolności, tak przy tejże wolności miasta zostawują się. Niemniej będzie wolno tymże miastom czynić rozporządzenia co do wewnętrznych porządków i uskutecznienia dozierać, o czym Komisję Policji uwiadomiać mają przez raporta". Później treść tej ustawy uznana została za część Konstytucji 3 Maja z 1791 roku (w rozdziale III Miasta i mieszczanie) ${ }^{4}$. Po upadku I Rzeczypospolitej rozwój in-

1 Natomiast zróżnicowany wcześniej status prawny parafii, wspólnot miejskich i wiejskich został zunifikowany ustawą z 22 grudnia 1789 r. W imię równości uznano, że każda wspólnota mieszkańców bez względu na jej rozmiary, charakter (miasto, wieś) i liczbę członków ma identyczny status prawny w zakresie: struktury, praw, obowiązków czy też gwarancji samodzielności.

2 Rozwiązania te zarówno z przyczyn strukturalnych (słabe przygotowanie fachowe osób pełniących rolę organów, niewystarczająca kontrola państwa), jak i politycznych (źródło opozycji wobec władzy centralnej, powstanie w Wandei) nie sprawdziły się i już w 1800 r. Napoleon w ramach przeprowadzonej przez siebie reformy administracyjnej przywrócił model administracji oparty o centralizację, pozostawiając gminy wyłącznie jako jednostki podziału terytorialnego (ich organy były mianowane przez rząd, stając się organami państwa).

3 Takie ujęcie gminy powtórzono później w konstytucji Belgii z 1830 r. Por. także T. Maciejewski, Samorzad terytorialny II Rzeczypospolitej (1918-1939), „Z Problemów Administracji. Administracja Publiczna" 2010, nr 2/1a, red. T. Maciejewski, J. Gierszewski, s. 18.

${ }^{4}$ M. Adamczyk, S. Pietruszka, Konstytucje polskie w rozwoju dziejowym 1791-1982, Warszawa 1985, s. 21, 36 . 
stytucji samorządu terytorialnego następował już w ramach systemów prawnych państw zaborczych.

Rozwijająca się idea samorządu tery torialnego znalazła podatny grunt w Prusach, gdzie reformom sprzyjał okres po klęsce w wojnie z Francją w roku 1806. Wielkim zwolennikiem samorządu terytorialnego był minister Karl vom und zum Stein. Uważał on, że „najdoskonalszą formą wypełniania funkcji państwowych jest wykonywanie pojedynczych lokalnych zadań państwa przez osoby wybrane, które by chciały dobrowolnie zadania te spełniać, jako swoje własne. Samorząd ma być wprowadzony, gdyż leży w interesie państwa, aby naród wyszedł ze stanu niemowlęctwa przez nadanie mu prawa decydowania o jego miejscowych prawach"5. W konsekwencji rozporządzeniem królewskim z 19 listopada 1808 roku w Prusach wprowadzona została ordynacja miejska (Preußische Städteordnung), która, opierając się na założeniach decentralizacji władzy, ustanawiała miasta jako podmioty publicznoprawne. Zresztą do pojęcia korporacji publicznej (öffentliche Kötperschaft) odwoływał się już Landrecht pruski z 1794 roku, obejmując tym mianem „wszelkiego rodzaju związki, utworzone dla celów »trwałych i powszechnie użytecznych «, łącząc z nimi możność wykonywania uprawnień władczych i uważaną za ich źródło osobowość publicznoprawną, identyfikowaną w wielu kierunkach z osobowością publicznoprawną państwa"6. Ostatecznie samorząd w Prusach ukształtował się w II połowie XIX wieku i obejmował gminy wiejskie i miejskie, powiaty oraz prowincje. Podstawowymi aktami dla najniższego stopnia samorządu były ustawa z 3 lipca 1891 roku — ordynacja dla gmin wiejskich oraz ustawa z 30 maja 1853 roku ordynacja miejska ${ }^{7}$. Mieszkańcy miast $w$ wyborach ${ }^{8}$ wyłaniali radę miejską na trzyletnią kadencję. Władzę wykonawczą sprawował magistrat powoływany przez radę na 6 lat. Na jego czele stał burmistrz lub nadburmistrz (w większych miastach), którzy byli powoływani przez cesarza spośród trzech kandydatów wskazanych przez radę. W gminach wiejskich (jednowioskowych) organem uchwałodawczym była rada gminy (w przypadku gmin obejmujących do 40 osób posiadających prawa wyborcze takim organem było ogólne zgromadzenie członków gminy) składająca się z 6 radnych wybieranych na sześcioletnią kadencję. Władzę wykonawczą sprawował naczelnik gminy wraz z ławnikiem. Kompetencje tego szczebla samorządu podzielono na własne (budowa i utrzymania dróg, szkół, zakładów leczniczych, pobór podatków i inne) oraz zlecone (poru-

5 Za: A. Kroński, Teorja samorządu terytorialnego, Warszawa 1932, s. 16. Dodać należy, że słowo „samorząd” jest swoistą kalką językową określenia tego rodzaju władzy lokalnej z języka niemieckiego - Selbstverwaltung, która sama jest skrótem wyrazów Selbständige i Verwaltung, co w języku polskim należałoby tłumaczyć jako samodzielny zarząd. Samorząd oznacza zatem samodzielne wykonywanie zarządu przez bezpośrednio zainteresowanych.

6 J. Filipek, Prawo administracyjne - instytucje ogólne, cz. 1, Kraków 2003, s. 105.

7 Zbiór Ustaw Pruskich — odpowiednio s. 233, 261.

8 Wybory do samorządu miejskiego były oparte o wysoki cenzus majątkowy i odbywały się w trzech kuriach, co powodowało przejęcie rad przez bogate mieszczaństwo. 
czone - obejmujące utrzymanie porządku publicznego przez miejscową policję). Na szczeblu powiatu organem uchwałodawczym był sejmik powiatowy (Kreistag) składający się z 25 osób. Wybierany był na 6 lat w systemie kurialnym, z tym że co 2 lata jedna trzecia składu była wymienienia. Zwoływany był raz w roku przez landrata (starostę), który także przewodniczył jego obradom ${ }^{9}$. Organem wykonawczym był wydział powiatowy (składający się z 6 członków wybieranych przez sejmik) na czele z landratem, który był mianowany przez monarchę spośród kandydatów przedstawionych przez sejmik. Wydział powiatowy realizował zadania własne i zlecone. Wreszcie na poziomie prowincji — najwyższej jednostki podziału administracyjnego Królestwa Prus - samorząd zaczął funkcjonować od 1879 roku. Organem uchwałodawczym był sejm prowincjonalny (Provinziallandtag) na czele z marszałkiem. Członków sejmu prowincjonalnego wybierały sejmiki powiatowe i rady miejskie. Organem wykonawczym był wydział prowincjonalny z dyrektorem krajowym na czele.

Utorowanie drogi do powstania samorządu w Austro-Węgrzech wiązać należy z upadkiem rządów absolutystycznych i zmianami politycznymi związanymi z wydaniem przez cesarza dyplomu październikowego z 20 października 1860 roku oraz patentu lutowego z 26 lutego 1861 roku. Przepisy samorządowe sformułowano w ustawie gminnej z dnia 12 sierpnia 1866 roku. Wprowadzono jednolitość ustrojową gmin wiejskich i miejskich, nadając im jednakowe uprawnienia. Co istotne, każda ukształtowana wieś stanowiła odrębną gminę niezależnie od wielkości bądź gęstości zaludnienia ${ }^{10}$. Organem uchwałodawczym była rada gminy wybierana w systemie kurialnym. Liczyła ona od 8 do 36 członków. Organem wykonawczym była tzw. zwierzchność gminna, która obejmowała naczelnika gminy (wójta) oraz kilku przysiężnych (asesorów — przynajmniej dwóch) wybieranych przez radę gminy. Zarówno rada gminy, jak i zwierzchność gminna były wybierane na okres 3 lat, a od 1884 roku na kadencję sześcioletnią. Gminy wykonywały zadania własne (w zakresie szkolnictwa, dróg gminnych, budżetu lokalnego, dobroczynności, organizacji policji miejscowej) i zlecone (m.in. zawierania ślubów cywilnych, statystyki ludności, poboru podatków i poboru do wojska). Rozszerzenie odrębności ustrojowych gmin miejskich nastąpiło w ustawie z 13 marca 1889 roku, która wprowadziła odrębną regulację dla 30 miast „większych” (oprócz Krakowa i Lwowa posiadających własne statuty — odpowiednio z 1866 i z 1870 roku) oraz w ustawie z 3 lipca 1896 roku dla pozostałych 131 mniejszych miast i miasteczek. Organami uchwałodawczymi były rady miejskie liczące 18-36 członków wybieranych na 6 lat (co trzy lata ustępowała połowa radnych). Znacznie

${ }^{9}$ Ewentualnie obradom przewodniczył najstarszy członek sejmiku.

10 Podobnie jak w Prusach były to tzw. gminy jednostkowe (jednowioskowe). Konsekwencją tego było duże zróżnicowanie poszczególnych gmin, a co za tym idzie ich możliwości ekonomicznych oraz wydolności w wykonywaniu zadań. 
liczniejsze były rady Lwowa (100 radnych) i Krakowa (72 radnych) ${ }^{11}$. Organami wykonawczymi we Lwowie, Krakowie oraz w 30 znaczniejszych miastach były magistraty wybierane przez rady na sześcioletnią kadencję. W wypadku Lwowa i Krakowa magistrat tworzyli prezydent z zastępcą oraz 20 radców, a w innych „większych” miastach — burmistrz z zastępcami i kilku asesorów. W mniejszych miastach i miasteczkach organami wykonawczymi były zwierzchności gminne z naczelnikiem gminy i kilkoma asesorami. Na szczeblu powiatu samorząd wprowadziła ustawa z 12 sierpnia 1866 roku o reprezentacji powiatowej. Organem uchwałodawczym była rada powiatowa składająca się z 26 członków wybierana przez mieszkańców w wyborach kurialnych na sześcioletnią kadencję. Organem wykonawczym był wydział powiatowy wybierany przez radę powiatową. Składał się on z prezesa i sześciu członków włącznie z zastępcą prezesa. Prezesa i jego zastępcę zatwierdzał monarcha. Chociaż nie było samorządu na szczeblu wojewódzkim, to na szczeblu Galicji mieliśmy do czynienia z autonomią z własnymi instytucjami: Sejmem Krajowym, Wydziałem Krajowym i Radą Szkolną Krajową.

Dodać także należy, że pewną specyfiką na terenach zaboru pruskiego i austriackiego były tzw. obszary dworskie tworzące odrębne jednostki organizacyjne niewchodzące w skład gmin, a których zarząd spoczywał w rękach ich właścicieli lub powołanych przez nich pełnomocników ${ }^{12}$.

W zaborze rosyjskim samorząd był słabo rozwinięty z ograniczonymi kompetencjami, a nadto jego struktura była zróżnicowana — inna na terenie byłego Królestwa Polskiego, inna na terenach bezpośrednio włączonych do Rosji. Wprawdzie na terenie byłego Królestwa Polskiego na mocy ukazu carskiego z 2 marca (19 lutego) 1864 roku powołano gminy wiejskie, brak było jednak samorządu miejskiego ${ }^{13}$. Powołana gmina wiejska była gminą zbiorową, dużą pod względem obszaru $^{14}$, a w jej skład wchodziły wsie - gromady $^{15}$ (czasem od kilku do kilkunastu), obszary dworskie (dwory i folwarki należące do właścicieli ziemskich) oraz osady (liczące często kilka tysięcy osób) ${ }^{16}$. Organami stanowiącymi były zebrania (zgromadzenia) gminne i gromadzkie, a organami wykonawczymi odpowiednio

$11 \mathrm{~W}$ roku $1909 \mathrm{w}$ związku z przyłączeniem do miasta szeregu gmin wiejskich podniesiono liczbę radnych o 11, a w 1915 r. jeszcze o 20.

$12 \mathrm{Na}$ ziemiach byłego zaboru austriackiego obszary te zlikwidowane zostały w 1919 r., a na ziemiach byłego zaboru pruskiego dopiero w 1933 r. Zob. szerzej W. Witkowski, Historia administracji w Polsce 1764-1989, Warszawa 2007, s. 318.

13 Wcześniej z inicjatywy Aleksandra Wielopolskiego został wydany ukaz carski z 24 maja (5 czerwca) 1861 r. o radach gubernialnych, o radach powiatowych i radach miejskich. Wybuch powstania styczniowego spowodował ich likwidację (rad gubernialnych nie zdołano nawet wybrać).

14 Wynikało to z polityki władz rosyjskich, ale także ze zróżnicowanej gęstości zaludnienia oraz z faktu, że miast było mało, gdyż po powstaniu styczniowym zniesiono ponad 300 miast. Zob. E. Ochendowski, Prawo administracyjne. Część ogólna, Toruń 2001, s. 284.

$15 \mathrm{~W}$ pewnym uproszczeniu odpowiednik dzisiejszego sołectwa.

16 Zob. szerzej S. Wójcik, Samorząd terytorialny w Polsce w XX wieku. Myśl samorządowa: historia i wspótczesność, Lublin 1999, s. 97. 
wójt i sołtys. Zebranie gminne tworzyli zamieszkali na terenie gminy właściciele co najmniej trzech mórg gruntu (w przypadku osad wymagano pół morgi), z wyjątkiem duchownych, sędziów pokoju i osób pełniących funkcje urzędnicze ${ }^{17}$. Do kompetencji zebrania wiejskiego należały: wybór wójta, ławników, urzędników gminnych, stanowienie i podział składek gminnych, rozporządzanie majątkiem oraz prowadzenie zakładów dobra publicznego. Zebranie gromadzkie miało natomiast charakter stanowy, gdyż uprawnionymi do udziału w nim byli wyłącznie pełnoletni włościanie - gospodarze mający w obrębie gromady własne domostwa i grunty, bez względu na ich powierzchnię. Ich zadania ograniczały się właściwie do wyboru sołtysa i uchwalania składek na potrzeby gromady. Należy także zwrócić uwagę, że wprawdzie formalnie wyboru wójta i sołtysa dokonywały zebrania, to jednak faktycznie były to nominacje rządowe, gdyż wybrana na takie stanowisko osoba musiała uzyskać akceptację naczelnika powiatu. W praktyce zebrania gminne i gromadzkie wybierały po dwóch kandydatów na stanowiska wójta i sołtysa, następnie ich nazwiska przedstawiano naczelnikowi powiatu. Ten zaś, jeżeli nie miał zastrzeżeń, jedną z przedstawionych osób powoływał na urząd, a drugą na jego zastępcę. Jednak w sytuacji, gdy naczelnik nie zaakceptował kandydatur, zarządzał ponowne wybory. Jeśli kolejny raz wybrano by kandydatów, których nie chciał zaakceptować, to mógł wnieść do gubernatora o zarządzenie trzecich i ostatecznych wyborów. Cała ta procedura akceptowania (odrzucania) kandydatów wybieranych w jawnym głosowaniu służyła de facto narzuceniu zebraniu właściwych (tj. lojalnych rządowi) kandydatów. Jednocześnie kandydatom nie stawiano żadnych, minimalnych nawet wymagań. W konsekwencji wójtami zostawały często osoby niewykształcone, a nawet nieposiadające umiejętności czytania i pisania, a więc szczególnie podatne na manipulację i chęć wykazania się lojalnością wobec administracji rządowej. Władza wójta było stosunkowo mocna, a wykonywane przezeń zadania obejmowały sprawy samorządu gminnego (wykonywanie uchwał zebrania wiejskiego, zarządzanie majątkiem gminy oraz zakładami dobra publicznego, pobieranie składek gminnych, zwierzchnictwo nad urzędnikami gminnymi itd.) oraz sprawy z zakresu administracji rządowej (z zakresu działania policji, bezpieczeństwa, administracji skarbowej itd.) ${ }^{18}$.

17 Podkreślić należy istotną trudność w sprawnym funkcjonowaniu takiego organu uchwałodawczego, który liczyć mógł nawet kilkuset zgromadzonych (co wymagało niekiedy prowadzenia obrad pod gołym niebem ze względu na brak odpowiednio dużych pomieszczeń i powodowało brak kworum), w większości osób niewykształconych, skłonnych bardziej do działań partykularnych niż w interesie gminy. Co ciekawe, tylko ważniejsze uchwały zebrania wiejskiego (np. dotyczące majątku, mające obowiązywać dłuższy czas lub też na żądanie zebrania) wymagały zaprotokołowania. Brak utrwalenia na piśmie treści podjętych uchwał prowadził do dużej swobody wójta w ich późniejszym wykonywaniu.

18 Ciekawą analizę funkcjonowania samorządu gminnego w Królestwie Polskim przedstawiają: T. Dziki, Administracja gmin wiejskich w Królestwie Polskim w latach 1815-1864, „Klio” 
Odmiennie przedstawiała się sytuacja na pozostałych ziemiach I Rzeczypospolitej włączonych bezpośrednio do Rosji, np. Polesiu i Wołyniu. Samorząd wiejski powołano tam w tym samym czasie co w innych guberniach Rosji, tj. w 1861 roku wraz z reformą chłopską. Co istotne, samorząd wiejski miał charakter stanowy (tworzono go wyłącznie na ziemiach chłopskich, wyłączając spod jego działania folwarki). Gmina miała także charakter gminy zbiorowej, a zebranie (zgromadzenie) gminne tworzyli przedstawiciele gromad (z dziesięciu domów delegowano 1 osobę). Zebrania odbywały się rzadko i nie miały większego znaczenia. Całość zarządzania gminą spoczywała na wójcie - całkowicie uzależnionym od władz rządowych. Stąd też w literaturze wprost oceniano, że gmina była tu jednostką administracyjną, a nie samorządową ${ }^{19}$. Na mocy ustawy o miastach z 16 czerwca 1870 roku wprowadzono w Rosji samorząd miejski - początkowo na obszarze Rosji centralnej, Syberii i Besarabii, a następnie dopiero rozciągnięto to prawo na gubernie zachodnie i nadbałtyckie (od 1876 roku). Organami samorządu miejskiego były rada miejska (pochodząca z wyborów, a której liczebność zależała od wielkości miasta) i zarząd miejski. Co do zasady czynne i bierne prawo wyborcze przysługiwało mężczyznom w wieku powyżej 25 lat, posiadającym nieruchomość określonej wartości (300, 1000 lub 3000 rubli — w zależności od wielkości miasta) bądź płacącym podatek przemysłowy lub handlowy w określonej wysokości. Rady miejskie obradowały co najmniej 4 razy w roku, a do ich zadań należały sprawy dotyczące zarządu majątkiem miejskim, budżetu, podatków na rzecz porządku publicznego, opieki zdrowotnej itd. Zarząd miejski składał się z wybranych przez radę: prezydenta (w mniejszych miastach burmistrza), 2-6 członków zarządu i sekretarza. Prezydent (burmistrz) i członkowie zarządu miejskiego byli urzędnikami państwowymi i byli zatwierdzani na swoje stanowiska - w zależności od wielkości miasta - przez gubernatora lub ministra spraw wewnętrznych. Oprócz uchwał rady zarząd wykonywał wiele zadań poruczonych przez państwo.

Na ziemiach włączonych bezpośrednio do Rosji nie wprowadzono także samorządu ziemskiego na szczeblu powiatu i guberni. Dopiero w 1911 roku w sześciu guberniach: mohylewskiej, witebskiej, mińskiej, kijowskiej, wołyńskiej i podolskiej, utworzono ziemstwa powiatowe i gubernialne na wzór tych, które istniały w guberniach rosyjskich (według ustawy z 12 czerwca 1890 roku) ${ }^{20}$. Organami uchwałodawczymi w ziemstwach były rady ziemskie, które zbierały się raz do roku, a organami wykonawczymi były zarządy składające się z 2-6 członków

2015, nr 1, s. 111 n.; B. Kołaczkowski, M. Ratajczak, Wpływ odzyskania niepodległości na kształt i zakres samodzielności władz samorzadu terytorialnego na ziemiach byłego zaboru rosyjskiego, „Studia Prawa Publicznego” 2013, nr 3, s. 161.

19 Zob. S.Kutrzeba, Historya ustroju Polski w zarysie, t. 3, Lwów 1920, s. 204.

${ }^{20}$ Natomiast w trzech guberniach: wileńskiej, grodzieńskiej i kowieńskiej nie wprowadzono ziemstw, utrzymując ich namiastkę, tj. ziemskie komitety gubernialne i powiatowe składające się z urzędników i osób mianowanych spośród miejscowej ludności. 
wybieranych przez rady. Chociaż ziemstwa te nie miały charakteru stanowego szlacheckiego $^{21}$ (wyborcami byli właściciele ziemscy i chłopi), to jednocześnie uregulowania ordynacji dyskryminowały Polaków ${ }^{22}$.

\section{Początki (etap I - lata 1918-1933)}

Powyższa charakterystyka pozwala uświadomić sobie, jak zróżnicowane systemy prawne funkcjonowały na obszarze odradzającego się państwa i jak odmienne były struktury administracji publicznej. Co więcej, zgodzić się należy z W. Witkowskim, że „w żadnej dziedzinie życia publicznego odrodzonego państwa różnice dzielnicowe nie zaznaczyły się tak silnie, jak w obszarze samorządu terytorialnego" ${ }^{23}$. Istniały więc wówczas co najmniej cztery typy samorządu terytorialnego, które nadto miały swoje dalsze modyfikacje. Pierwszy okres budowania struktur samorządowych w Polsce i próby zbliżenia funkcjonujących dotychczas modeli opierał się więc na regulacjach i wzorcach odziedziczonych po zaborcach. Złożyło się na to kilka elementów. Przede wszystkim pamiętać należy, że 11 listopada 1918 roku jest jedynie datą symboliczną i nie nastąpiło wówczas objęcie efektywną kontrolą przez centralne władze polskie wyznaczonego granicami terytorium. Był to pewien rozciągnięty w czasie proces, którego pierwszy etap polegał na podporządkowywaniu się władzom centralnym poszczególnych lokalnych ośrodków władzy polskiej, a drugi na kształtowaniu się granic zewnętrznych Polski względem innych państw. To właśnie te problemy ogólnopaństwowe związane najpierw z wojną polsko-bolszewicką, a także równolegle $\mathrm{z}$ kształtowaniem się granic z Czechosłowacją (na Spiszu, Orawie, Zaolziu), Niemcami (w Wielkopolsce, na Górnym Śląsku, Pomorzu Gdańskim, Warmii i Mazurach) i Litwą, a później także trudności związane ze stabilizacją gospodarczą, zwalczaniem hiperinflacji itd. przede wszystkim absorbowały władze państwowe. Pracom nad ujednolicaniem modelu i struktur samorządu terytorialnego nie sprzyjała także wewnętrzna sytuacja polityczna prowadząca do częstej zmiany rządów, różnice w poziomie rozwoju gospodarczego i gęstości zaludnienia poszczególnych ziem oraz kwestie związane z mniejszościami narodowymi ${ }^{24}$. Przede wszystkim jednak brak było

$21 \mathrm{~W}$ przeciwieństwie do istniejących od 1864 r. na pozostałym obszarze imperium rosyjskiego.

${ }^{22}$ Zob. B. Wasiutyński, Ustrój władz administracyjnych rzadowych i samorządowych, Poznań 1937, s. 87; A. Pragier, Zarys skarbowości komunalnej, cz. 1, Warszawa 1924 (autor ten szczegółowo omawia rozwój samorządu terytorialnego w Europie w XIX wieku, w tym oczywiście na ziemiach polskich); J. Folejewski, T. Wróblewski, O samorządzie ziemskim na Litwie i Białejrusi, Wilno 1910, s. 15, $31 \mathrm{n}$.

23 W. Witkowski, Historia administracji w Polsce 1764-1989, Warszawa 2007, s. 341.

24 Szerzej zob. A. Chojnowski, Koncepcje polityki narodowościowej rządów polskich w latach 1921-1939, Wrocław 1979. 
gotowej, spójnej koncepcji budowy struktur samorządu terytorialnego ${ }^{25}$, a wyżej wskazane czynniki nie sprzyjały także jej szybkiemu wypracowaniu ${ }^{26}$. Słusznie zatem władze centralne, mające wówczas istotniejsze cele związane z utrwalaniem odzyskanej niepodległości Polski, przyjęły wariant ewolucyjny, a nie rewolucyjny w kreowaniu struktur administracji publicznej, a zwłaszcza lokalnej — samorządowej. Oparto się więc na dotychczasowych strukturach administracyjnych znanych miejscowej ludności, do których była ona przyzwyczajona, modyfikując je tylko nieco (w kierunku demokratyzacji, niwelacji różnic i osiągnięcia pewnych pożądanych standardów).

\section{Gmina}

Podstawowym aktem z tego pierwszego okresu jest Dekret z 27 listopada 1918 roku o utworzeniu rad gminnych na obszarze byłego Królestwa Kongresowego ${ }^{27}$. Dekretem tym do dotychczasowej regulacji rosyjskiej wprowadzono powszechność głosowania (zniesiono cenzus płci i majątku, a jedynymi cenzusami były: wiek — skończonych 21 lat, domicyl — zamieszkiwanie w gminie od 6 miesięcy oraz polska przynależność państwowa (art. 12 dekretu). Nadto utworzono radę gminy składającą się z wójta i 12 członków (będącą swego rodzaju reprezentacją ludności czuwającą m.in. nad wykonywaniem uchwał zgromadzenia gminnego i kontrolującą działalność wójta — art. 7 dekretu) wybieranych przez zgromadzenie gminne (organ uchwałodawczy). Zniesiono wymóg zatwierdzania kandydatów na wójta (art. 3 dekretu), wprowadzając jednocześnie obowiązek

25 Wynikało to m.in. z odmiennych poglądów na ten temat w programach poszczególnych ugrupowań politycznych. Szerzej zob. J. Starościak, Decentralizacja administracji, Warszawa 1960, s. 85-87; H. Izdebski, Historia administracji, Warszawa 1997, s. 148-149; Z. Bukowski, T. Jędrzejewski, P. Rączka, Ustrój samorządu terytorialnego, Toruń 2013, s. 43. Należało chociażby rozstrzygnąć, jaki model gminy przyjąć: jednolity czy odrębny dla gminy wiejskiej i miejskiej; jednostkowej czy zbiorowej. Kontrowersje budziło nawet to, czy wybory do organów stanowiących powinny być powszechne, czy też oparte na określonym cenzusie. Ugrupowania prawicowe opowiadały się za tworzeniem struktur samorządu terytorialnego z zachowaniem silnej władzy centralnej. Natomiast partie lewicowe opowiadały się za wprowadzeniem szerokiej samodzielności jednostek samorządu terytorialnego. Szerzej zob. M. Sidor, Samorząd terytorialny w myśli politycznej II Rzeczypospolitej, Toruń 2010; A. Bosiacki, Od naturalizmu do etatyzmu. Doktryny samorzadu terytorialnego Drugiej Rzeczypospolitej 1918-1939, Warszawa 2006.

26 Jak wskazuje I. Lipowicz dodatkową przeszkodą był także opór ówczesnych przedstawicieli władz samorządowych wynikający z napięć politycznych między województwami wschodnimi i zachodnimi oraz dostrzegalny w debatach ,ton wyższości »cywilizacyjnej« województw zachodnich". I. Lipowicz, Tradycje i przyszłość samorzadu terytorialnego w świetle nauki prawa administracyjnego, [w:] Między tradycją a przyszłością w nauce prawa administracyjnego. Księga jubileuszowa dedykowana Profesorowi Janowi Bociowi, red. J. Supernat, Wrocław 2009, s. 430.

27 Dziennik Praw Państwa Polskiego Nr 18, poz. 48 (dalej: Dz.P.P.P.). 
umiejętności czytania i pisania po polsku dla kandydatów na stanowisko wójta oraz wymóg ukończenia 25 lat życia (art. 4 dekretu). Nakazano także zapisywanie uchwał samorządowych w specjalnej „księdze protokułów” (art. 10 dekretu). Kadencję („okres urzędowania członków Rady Gminnej”) ustalono na 3 lata.

Podstawowym aktem kształtującym samorząd na pozostałych ziemiach wschodnich Rzeczypospolitej było Rozporządzenie Komisarza Generalnego Ziem Wschodnich z dnia 26 września 1919 roku o samorządzie gminnym ${ }^{28}$. Na jego mocy zniesiono stanowy (wyłącznie chłopski) charakter samorządu, a jako organy samorządu gminnego wskazano pochodzącą z wyborów radę gminy (jako organ stanowiący i kontrolny) oraz zarząd (jako organ wykonawczy) składający się z wójta, jego zastępcy i ławnika. Radnych wybierało na trzyletnią kadencję zebranie wiejskie. Wójt stał na czele zarządu, ale także pełnił funkcje przewodniczącego rady gminy. Wykonywał on zadania własne i zlecone (por. art. 1, 2, 17, 22, 23 i 39 cyt. rozporządzenia). Gmina miała charakter zbiorowy, dzieląc się na gromady (oddzielne wsie, kolonie, osady, zaścianki, folwarki), a organami gromady były zebranie gromadzkie i sołtys ${ }^{29}$.

Powołany został także samorząd miejski na mocy Dekretu z dnia 4 lutego 1919 roku o samorządzie miejskim ${ }^{30}$. Gmina miejska uzyskała status samodzielnej jednostki samorządu oraz osoby prawa publicznego (art. 2 dekretu). Organem uchwałodawczym i kontrolnym ustanowiono radę miejską, a organem wykonawczym - magistrat ${ }^{31}$. Rada miejska składała się z radnych (wybieranych w wyborach tajnych na okres 3 lat) oraz członków magistratu (art. 12, 13, 20, 40 i 46 dekretu), a jej liczebność wahała się od 12 do 70 (ale np. dla Warszawy było to 120 radnych, a dla Łodzi 75). Co ciekawe, radni pełnili swoje funkcje honorowo (art. 16 dekretu), a w przypadku wyboru radnego na członka magistratu tracił on mandat, a na jego miejsce wchodził tzw. zastępca (art. 14 dekretu) ${ }^{32}$. Co do zasady czynne

28 Dziennik Urzędowy Zarządu Cywilnego Ziem Wschodnich z 1919 r. Nr 21, poz. 215.

29 Zob także M. Gałędek, Odrębności ustroju samorzadu terytorialnego na ziemi wileńskiej wokresie międzywojennym, „Z Problemów Administracji. Administracja Publiczna” 2010, nr 2/1a, red. T. Maciejewski, J. Gierszewski, s. 25 n.; oraz M. Gałędek, Ustrój administracji ogólnej na Wileńszczyźnie w okresie międzywojennym, Gdańsk 2013.

30 Dz.P.P.P. Nr 13, poz. 140.

31 Jako ciekawostkę można wskazać, że magistrat miał prawo „żądania rewizji” uchwał rady miejskiej, jeżeli 1) przekraczały zakres działalności rady; 2) naruszały statut miejski lub obowiązujące ustawy; 3) były „niewykonalne” lub mogły przynieść „,szkodę miastu”. Magistrat mógł zatem wpływać pośrednio na rozstrzygnięcia rady miejskiej, blokując uchwały z powołaniem się na tak nieostre sformułowania, jak ,niewykonalność” lub „szkodę”. Jednak tak zakwestionowana uchwała wchodziła w życie, jeżeli na następnym posiedzeniu rady przyjęto ja większością $2 \frac{2}{3}$ głosów. O ile rada miejska zdołała przełamać taką blokadę przy wewnętrznej spójności dającej odpowiednią większość, to jednak w wielu przypadkach magistrat mógł skutecznie blokować dużą część uchwał organu stanowiącego.

32 Wobec wyczerpania liczby „zastępców” w danym okresie wyborczym i jednocześnie braku więcej niż 10\% ogólnej liczby radnych, burmistrz bądź prezydent miasta zarządzał wybory uzupełniające (art. 15 dekretu). 
prawo wyborcze przysługiwało wszystkim mieszkańcom, którzy: ukończyli 21 lat, mieli obywatelstwo polskie oraz stale mieszkali na terenie danej gminy przynajmniej od 6 miesięcy ${ }^{33}$. Natomiast bierne prawo wyborcze przysługiwało osobom, którym przysługiwało prawo czynne, mającym ukończone 25 lat oraz umiejącym pisać i czytać po polsku (art. 4 dekretu o wyborach do rad miejskich na terenie b. Królestwa Kongresowego). Przewodniczącymi magistratów miast wydzielonych, tj. stanowiących osobny powiatowy samorząd miejski, byli prezydenci, a pozostałych miast - burmistrzowie. Obok prezydenta (burmistrza) w skład magistratu wchodzili jego zastępcy oraz ławnicy (w liczbie stanowiącej 10\% składu rady). Samorząd miejski wykonywał zarówno zadania własne, jak i zadania poruczone z zakresu administracji rządowej (por. art. 9-11 dekretu o samorządzie miejskim).

$\mathrm{Na}$ ziemiach wschodnich kwestię samorządu miejskiego regulowały dwa akty — rozporządzenia Komisarza Generalnego Ziem Wschodnich: z 27 czerwca i z 14 sierpnia 1919 roku. Pierwsze z tych rozporządzeń powoływało magistraty pochodzące z nominacji władz państwowych (w miejsce tych ustanowionych na mocy rosyjskich uregulowań) ${ }^{34}$. Drugie zaś kształtowało ustrój gmin miejskich na zasadach przyjętych dla byłego Królestwa Polskiego w tych większych miastach, w których oceniono, że istniały dogodne warunki dla działalności takich organów. $\mathrm{Z}$ czasem poszerzano liczbę tych miast, tak że po 1927 roku wszystkie miasta na ziemiach wschodnich miały ustrój tożsamy z miastami w byłym Królestwie (jedynie kwestie nadzoru były nieco inaczej — bardziej restrykcyjnie — określone).

Jeżeli chodzi o ziemie byłego zaboru austriackiego i pruskiego, to zmiany były tu niewielkie. Funkcjonowanie samorządu terytorialnego opierało się oczywiście na dotychczasowych regulacjach, przeprowadzono jedynie demokratyzację struktur samorządu na ziemiach byłego zaboru austriackiego przez wprowadzenie dodatkowej (czwartej) kurii wyborczej dla osób nieopodatkowanych i bez wykształcenia ${ }^{35}$, a istniejące w Galicji Wschodniej obszary dworskie zrównano z gminami ${ }^{36}$. Natomiast na ziemiach byłego zaboru pruskiego zgodnie z rozporządzeniem Ministra byłej Dzielnicy Pruskiej z 25 marca 1920 roku $^{37}$ pozostawiono

33 Szczegóły regulował Dekret z dnia 13 grudnia 1918 r. o wyborach do rad miejskich na terenie b. Królestwa Kongresowego (Dz.U. z 1918 r. Nr 20, poz. 58).

34 Jak wskazuje A. Pragier, rozporządzenie to dotyczyło miast, w których według władz polskich było niemożliwe lub niewskazane powołanie do życia wybieralnych organów samorządu miejskiego (m.in. ze względów narodowościowych — przewagi ludności pochodzenia niepolskiego). A. Pragier, op. cit., s. 172.

35 Uczyniła to jeszcze Polska Komisja Likwidacyjna rozporządzeniem z 23 listopada $1918 \mathrm{r}$. Zob szerzej: Z. Pazdro, Przemiany ustrojowe samorzadu terytorialnego na obszarze bytej Galicji (1918-1939), Lwów 1939, s. 5; R. Szwed, Samorządowa Rzeczpospolita 1918-1939, Częstochowa 2000, s. 10.

36 Na mocy Ustawy z dnia 26 lipca 1919 r. o połączeniu obszarów dworskich z gminami, obowiązującej na terytorium b. Galicji (Dz.U. z 1919 r. Nr 67, poz. 404).

37 Dalszych zmian w ordynacji z 3 lipca 1891 r. dokonano na podstawie rozporządzenia Ministra b. Dzielnicy Pruskiej z 7 sierpnia 1920 r. 
gminy jednowioskowe, a prawo znoszenia dotychczasowych i tworzenia nowych przysługiwało rządowi Rzeczypospolitej. Organami uchwalającymi i kontrolującymi w gminie były zgromadzenie gminne i rada gminna. Zgromadzenie funkcjonowało w gminach do stu członków i tworzyli je wszyscy mieszkańcy gminy, którzy ukończyli 20 lat oraz na stałe zamieszkiwali w gminie. W pozostałych gminach (liczących powyżej stu mieszkańców) wybierano radę gminną, wtedy na 20 wyborców przypadał jeden radny. Władzą wykonawczą był zarząd gminy składający się z sołtysa i ławników, wybierany przez zgromadzenia lub radę na okres 3 lat. Wprowadzono także nową ordynację wyborczą dostosowaną swoimi rozwiązaniami do tych, które obowiązywały na ziemiach byłego zaboru rosyjskiego.

\section{Powiat}

Powołany został także, wcześniej nieistniejący na ziemiach byłego Królestwa, samorząd na szczeblu powiatowym na podstawie wydanego 5 grudnia 1918 roku Dekretu o tymczasowej ordynacji wyborczej do Sejmików Powiatowych oraz Dekretu o tymczasowej ordynacji powiatowej dla obszarów Polski byłego zaboru rosyjskiego z 4 lutego 1919 roku $^{38}$. Powiat był związkiem komunalnym wyposażonym w osobowość publicznoprawną (art. 1 dekretu z 4 lutego 1919 roku). Podobnie jak w przypadku samorządu gminnego, również powiatom przyznano zadania własne i zadania poruczone (art. 5-8 dekretu z 4 lutego 1919 roku). Zostały wyodrębnione powiaty ziemskie, które składały się z gmin wiejskich i miast niewydzielonych, oraz powiaty miejskie, tj. miasta liczące ponad 25 tys. mieszkańców (tzw. miasta wydzielone z powiatów - art. 3 dekretu). Organami powiatu były: sejmik powiatowy (jako organ uchwałodawczy i kontrolny) oraz wydział powiatowy ze starostą na czele (jako organ wykonawczy). W skład sejmiku wchodziło po dwóch przedstawicieli każdej gminy wiejskiej i od dwóch do pięciu przedstawicieli rad miejskich. Przewodniczącym sejmiku był starosta, który pełnił jednocześnie funkcję organu administracji rządowej ${ }^{39}$. Natomiast wydział powiatowy składał się ze starosty i sześciu członków wybieranych przez sejmik spośród mieszkańców powiatu. Kadencja sejmiku i wydziału trwała 3 lata (art. 12 i 33 dekretu).

Te wzorce samorządu powiatowego były następnie powielane na pozostałych ziemiach wschodnich przejmowanych przez Polskę, znosząc na tych terenach instytucje ziemskie utworzone na mocy regulacji rosyjskich. Istotne było w tej mierze Rozporządzenie Rady Ministrów z dnia 10 sierpnia 1922 roku w przedmiocie rozciągnięcia na województwa: nowogródzkie, poleskie i wołyńskie oraz

38 Dz.P.P.P. Nr 134, poz. 141.

39 Takie rozwiązanie niewątpliwie wzmacniało pozycję starosty, który jako szef administracji ogólnej i przedstawiciel rządu zyskiwał szerokie uprawnienia - miało to na celu zapewnienie sprawności i szybkości działania administracji publicznej. 
powiaty: grodzieński i wołkowyski województwa białostockiego mocy obowiązującej dekretów o tymczasowej ordynacji wyborczej dla sejmików powiatowych, o tymczasowej ordynacji powiatowej o skarbowości powiatowych związków komunalnych i ustawy w sprawie delegatów od miast w sejmikach powiatowych ${ }^{40}$ oraz Rozporządzenie Rady Ministrów z dnia 10 sierpnia 1922 roku w przedmiocie rozciągnięcia na Ziemię Wileńską mocy obowiązującej dekretów o tymczasowej ordynacji wyborczej dla sejmików powiatowych, o tymczasowej ordynacji powiatowej o skarbowości powiatowych związków komunalnych i ustawy w sprawie delegatów od miast w sejmikach powiatowych ${ }^{41}$.

Natomiast na ziemiach byłego zaboru pruskiego i austriackiego nie nastąpiły większe zmiany w zakresie dotychczasowego funkcjonowania samorządu na szczeblu powiatu ${ }^{42}$. Jedynie na terenie Śląska Cieszyńskiego nie powołano struktur powiatowych.

\section{Województwo}

Największe problemy wiązały się z utworzeniem samorządu terytorialnego na poziomie województw. Stosowny wzorzec istniał tylko na ziemiach byłego zaboru pruskiego. Dodatkowe komplikacje wiązały się z samym podziałem kraju na województwa oraz trwającymi na wschodzie działaniami wojennymi prowadzącymi do ostatecznego ukształtowania się granic państwa. Z powyższych przyczyn jako pierwsze utworzone zostały w sierpniu 1919 roku województwa poznańskie i pomorskie, na mocy Ustawy z dnia 1 sierpnia 1919 roku o tymczasowej organizacji zarządu b. dzielnicy pruskiej ${ }^{43}$, a następnie województwa warszawskie (odrębny statut województwa uzyskało m.st. Warszawa), łódzkie, kieleckie, lubelskie oraz białostockie na mocy Ustawy tymczasowej z dnia 2 sierpnia 1919 roku o organizacji władz administracyjnych II instancji ${ }^{44}$. Na podstawie Ustawy z dnia 3 grudnia 1920 roku o tymczasowej organizacji władz administracyjnych II instancji (województw) na obszarze b. Królestwa Galicji i Lodomerji z W. Ks. Krakowskiem oraz

40 Dz.U. z 1922 r. Nr 72, poz. 651.

41 Dz.U. z 1922 r. Nr 72, poz. 652.

42 Na podstawie Rozporządzenia Ministra b. Dzielnicy Pruskiej z dnia 12 sierpnia $1921 \mathrm{r}$. o wyborach do Sejmików Powiatowych na obszarze b. Dzielnicy Pruskiej wprowadzono m.in. wybory mieszane (częściowo pośrednie, częściowo bezpośrednie), ustalono czteroletnią kadencję sejmiku powiatu i wydziału powiatowego, czynne prawo wyborcze przyznano obywatelom polskim, którzy ukończyli 21 lat w dniu wydania rozporządzenia i mieli miejsce zamieszkania na terenie powiatu, a bierne prawo wyborcze przysługiwało obywatelom polskim, którzy ukończyli 25 lat, zamieszkiwali na terenie powiatu oraz władali językiem polskim w mowie i piśmie (Dz.U. z 1921 r. Nr 71, poz. 492).

43 Dz.P.P.P. z 1919 r. Nr 64, poz. 385.

44 Dz.P.P.P. z 1919 r. Nr 65, poz. 395. 
na wchodzących w skład Rzeczypospolitej Polskiej obszarach Spisza i Orawy ${ }^{45}$ utworzono województwa: krakowskie, lwowskie, stanisławowskie oraz tarnopolskie. W miarę stabilizacji granicy wschodniej na mocy Ustawy z dnia 4 lutego 1921 roku o unormowaniu stanu prawno-politycznego na ziemiach przyłączonych do obszaru Rzeczypospolitej na podstawie umowy o preliminaryjnym pokoju i rozejmie podpisanej w Rydze dnia 12 października 1920 roku $^{46}$ utworzono województwa: poleskie, nowogródzkie oraz wołyńskie, a jako ostatnie województwo wileńskie na mocy Ustawy z dnia 22 grudnia 1925 roku w sprawie utworzenia województwa wileńskiego ${ }^{47}$. Nadto Ustawą z dnia 16 sierpnia 1938 roku o samorządzie m.st. Warszawy określono ją jako jednostkę samorządu terytorialnego gminnego, powiatowego i wojewódzkiego ${ }^{48}$. Odrębnym województwem, którego ustrój kształtowano jednak nie na ogólnych zasadach, lecz w formule autonomii, było województwo śląskie. Zostało ono utworzone na mocy Ustawy konstytucyjnej z dnia 15 lipca 1920 roku zawierającej statut organiczny Województwa Śląskiego ${ }^{49}$.

Proces tworzenia administracji na szczeblu wojewódzkim był zatem rozciągnięty w czasie, a ponadto powołanie tych struktur nie oznaczało jednocześnie tworzenia samorządu na tym szczeblu. Samorząd wojewódzki de facto funkcjonował w II Rzeczypospolitej jedynie na terenie województw poznańskiego i pomorskiego, przejmując zadania i majątek pruskiego samorządu prowincjonalnego ${ }^{50}$. Jego organem uchwałodawczym i kontrolnym był sejmik wojewódzki (krajowy) wybierany na 4 lata przez sejmiki powiatowe i rady miast wydzielonych ${ }^{51}$. Natomiast organami wykonawczymi były wydział wojewódzki oraz starosta krajowy ${ }^{52}$. Wydział wojewódzki składał się z przewodniczącego wydziału oraz jego zastępcy, starosty krajowego i członków (12 w województwie poznańskim i 8 w woje-

45 Dz.U. z 1920 r. Nr 117, poz. 768.

46 Dz.U. z 1921 r. Nr 16, poz. 93.

47 Dz.U. z 1926 r. Nr 6, poz. 29.

48 Dz.U. z 1938 r. Nr 63, poz. 479, art. 1.

49 Dz.U. z 1920 r. Nr 73, poz. 497. Utworzone województwo śląskie składało się z dwóch części: cieszyńskiej i górnośląskiej. Organami województwa śląskiego były: Sejm Śląski (organ stanowiący składający się z 48 posłów z kompetencjami m.in. podziału administracyjnego województwa) oraz rada wojewódzka (organ wykonawczy liczący 5 osób), na czele której stał wojewoda (mianowany przez Naczelnika Państwa, a potem Prezydenta RP). Członkowie rady wojewódzkiej byli wybierani przez Sejm Śląski.

50 Początkowo przyjmując nazwy Poznański Krajowy Związek oraz Pomorski Komunalny Związek Krajowy, a następnie Poznański Wojewódzki Związek Komunalny oraz Pomorski Wojewódzki Związek Komunalny.

51 Poznański Sejmik Wojewódzki liczył 85 członków, a Pomorski Sejmik Wojewódzki liczył 55 członków. Zob. Rozporządzenie Ministra b. Dzielnicy Pruskiej z dnia 12 sierpnia 1921 r. o wyborach do Sejmików Wojewódzkich (Dz.U. z 1921 r. Nr 71, poz. 491).

52 Starostami krajowymi w okresie międzywojennym byli w województwie poznańskim Wacław Wyczyński i Ludwik Begale, a w województwie pomorskim Józef Wybicki i Wincenty Łącki. 
wództwie pomorskim). Byli oni wybierani przez sejmik wojewódzki niekoniecznie spośród jego członków. Wydział wojewódzki zwoływany był tak często, jak tego wymagały sprawy samorządu, a uchwały zapadały większością głosów. Zakres działań tych organów w zasadzie opierał się na ustawie króla Prus z 19 maja 1889 roku ${ }^{53}$. W szczególności wydział przygotował sprawy mające być przedmiotem obrad sejmiku wojewódzkiego oraz wykonywał uchwały sejmiku, o ile sejmik nie powierzył wykonania ich specjalnym komisjom, a także administrowanie majątkiem. Starosta krajowy był wybierany przez sejmik wojewódzki na okres 6-12 lat, z tym że jego wybór musiał zatwierdzić minister spraw wewnętrznych. Reprezentował on samorząd wojewódzki na zewnątrz, a swoje funkcje wykonywał z pomocą starostwa krajowego, którym kierował.

Na pozostałym obszarze kraju podstawy funkcjonowania samorządu na szczeblu województwa miała tworzyć Ustawa z dnia 26 września 1922 roku o zasadach powszechnego samorządu wojewódzkiego, a w szczególności województwa lwowskiego, tarnopolskiego i stanisławowskiego ${ }^{54}$. Akt ten wszedł w życie 25 października 1922 roku i przewidywał, że województwa, zgodnie z art. 65 konstytucji marcowej, są jednostkami samorządowymi. Organem stanowiącym miał być sejmik wojewódzki zwoływany (i odraczany) przez Prezydenta RP przynajmniej raz na rok, mógł on także sejmik rozwiązać (art. 5). Posłowie do sejmiku mieli być wybierani wedle odrębnej ordynacji wyborczej. W sprawach przekazanych samorządowi wojewódzkiemu sejmiki mały prawo uchwalać ustawy w granicach postanowień konstytucji oraz ustaw państwowych. Owe ustawy wojewódzkie nabierały mocy obowiązującej na obszarze województwa przez sankcję Prezydenta RP, zaopatrzoną w kontrasygnatę Prezesa Rady Ministrów i właściwego ministra, oraz ogłoszenie w dzienniku urzędowym województwa. Na podstawie ustaw wojewódzkich sejmiki mogły uchwalać postanowienia natury administracyjnej (art. 3). Organami wykonawczymi województw samorządowych miały być wydziały wojewódzkie na czele z wojewodą. W sposób szczególny zostały uregulowane zadania i struktura organizacyjna na obszarze województw lwowskiego, stanisławowskiego i tarnopolskiego. W województwach tych sejmiki miały być dwuizbowe (sejmik lwowski miał liczyć 100 członków $^{55}$, a stanisławowski i tarnopolski po 60 członków $^{56}$ ), z których jedną tworzyć mieli „posłowie kurji ruskiej”. Obie izby miały obradować i podejmować uchwały osobno pod kierownictwem wybranych przez siebie przewodniczących. Natomiast w sprawach wspólnych uchwała

53 Gesetz über die allgemeine Landesverwaltung und über die Zuständigkeit der Verwaltungsund Verwaltungsgerichtsbehörden in der Provinz Posen.

54 Dz.U. z 1922 r. Nr 90, poz. 829. Ustawa ta była nazywana „eksportową”, gdyż została uchwalona celem pozyskania przychylności państw Ententy dla akceptacji granicy wschodniej Polski. Dlatego też zawierała szczegółowe regulacje dotyczące wymienionych w niej trzech województw południowo-wschodnich, uwzględniające w swojej odrębności mniejszość „ruską”.

55 Po 50 członków na każdą z izb.

56 Po 30 członków na każdą z izb. 
musiała zyskać akceptację obu izb, a w sprawach dotyczących tylko jednej izby wystarczała uchwała tylko jednej właściwej izby. Regulacje zawarte w ustawie z 25 października 1922 roku nie zostały jednak wprowadzone w życie.

Swego rodzaju namiastką samorządu województwa na terenach byłego zaboru austriackiego był do 1928 roku Tymczasowy Wydział Samorządowy o niewielkich kompetencjach, a na ziemiach byłego zaboru rosyjskiego rady wojewódzkie. Funkcje Tymczasowego Wydziału Samorządowego we Lwowie były z czasem coraz bardziej ograniczane $e^{57}$, aż przeją je jego likwidator - wojewoda lwowski ${ }^{58}$. Natomiast rady wojewódzkie były organami opiniodawczymi powołanymi przy wojewodzie na podstawie Ustawy tymczasowej z dnia 2 sierpnia 1919 roku o organizacji władz administracyjnych II instancji ${ }^{59}$. Ustawa ta ogólnie określała organizację rad wojewódzkich i zakres ich kompetencji, do których należało wydawanie opinii w sprawach poddanych pod jej obrady przez wojewodę oraz podejmowanie uchwał stanowczych w sprawach przekazywanych jej przez ustawy (art. 4) ${ }^{60}$. W skład rady wojewódzkiej wchodził wojewoda (lub wyznaczony przez niego zastępca), jako jej przewodniczący, kierownicy poszczególnych działów administracji państwowej w województwie oraz przedstawiciele sejmików rad miast stanowiących powiaty (po jednym z każdego z tych ciał — art. 5). Uchwały stanowcze rady wojewoda mógł zawiesić, przekazując je celem ostatecznego rozstrzygnięcia właściwemu ministrowi. Od orzeczeń rady służyło odwołanie do właściwego dla danej sprawy ministra (chyba że wydane były „,w trzeciej instancji” lub ustawy wskazywały, które orzeczenia wydane w II instancji są ostateczne - art. 6). Rada wojewódzka wydawała opinie bądź podejmowała uchwały na posiedzeniach plenarnych lub

57 Zob. Sprawozdanie z czynności Tymczasowego Wydziału Samorządowego we Lwowie za czas od 1. Stycznia 1923 r. do 31. grudnia 1924 r., Lwów 1926 r.; D. Wrabec, Tymczasowy Wydziat Samorzadowy, Lwów 1933; R. Tomczyk, Od namiestnika do wojewody. Likwidacja zaborczego systemu prawno-administracyjnego w Galicji w okresie budowy II Rzeczypospolitej (1918-1921). Wybrane zagadnienia, „Zeszyty Naukowe Uniwersytetu Rzeszowskiego” 2010, nr 64, s. 129 n.; Ustawa z dnia 30 stycznia 1920 r. o zniesieniu Sejmu i Wydziału Krajowego b. Królestwa Galicji i Lodomerji z Wielkiem Księstwem Krakowskim (Dz.U. z 1920 r. Nr 11, poz. 61); Rozporządzenie Prezydenta Rzeczypospolitej z dnia 10 grudnia 1924 r. o reorganizacji Tymczasowego Wydziału Samorządowego we Lwowie przez redukcję urzędników, (Dz.U. z 1924 r. Nr 107, poz. 969).

58 Rozporządzenie Prezydenta Rzeczypospolitej z dnia 16 stycznia 1928 r. o zniesieniu Tymczasowego Wydziału Samorządowego we Lwowie (Dz.U. z 1928 r. Nr 7, poz. 40).

59 Dz.U. z 1919 r. Nr 65, poz. 395.

60 „Wojewoda powinien zasięgać opinii rady wojewódzkiej we wszystkich sprawach większego znaczenia dla województwa, tak pod względem gospodarczym jak i kulturalnym, a w szczególności w sprawach aprowizacyjnych, budowy kolei, kanałów, portów, regulacji rzek, zmiany granic województwa i powiatów, ulg podatkowych [...], budowy większych szpitali, nakładów humanitarnych itp. oraz we wszystkich sprawach ważniejszych wchodzących w zakres działania związków komunalnych" - art. 32 Rozporządzenia wykonawczego Rady Ministrów do ustawy tymczasowej z dnia 2 sierpnia 1919 r. „o organizacji władz administracyjnych drugiej instancji” (Dz.U. z 1919 r. Nr 90, poz. 490). 
w sekcjach. Wojewoda zwoływał plenarne posiedzenia rady w miarę potrzeby, nie rzadziej jednak niż dwa razy w roku.

Zatem struktury samorządowe na szczeblu województwa istniały jedynie w województwie poznańskim, pomorskim i (w formie autonomii) śląskim, co wiązało się z wcześniejszą tradycją i praktyką funkcjonowania tego poziomu samorządu na tych ziemiach oraz w Warszawie, której przyznano status województwa. Natomiast w innych województwach do wybuchu II wojny światowej nie powołano na tym poziomie struktur samorządu. Wynikało to z różnych przyczyn natury politycznej, związanych zarówno z dążeniem do wzmocnienia scentralizowanej administracji rządowej w terenie, jak i np. $\mathrm{z}$ kwestią stosunkowo dużego odsetka mniejszości narodowych zamieszkujących na kresach wschodnich (przede wszystkim ukraińskiej). Ta druga kwestia wiązała się z politycznym sporem co do udziału mniejszości w strukturach samorządu, także w administracji publicznej jako takiej, a nawet przyznania autonomii mniejszościom narodowym ${ }^{61}$. Dlatego też poza wspomnianymi województwami nie zdecydowano się na utworzenie samorządu wojewódzkiego na terenie całego kraju.

Po przewrocie majowym zaniechano prac związanych z unifikacją samorządu terytorialnego, koncentrując się nad zmianami prowadzącymi do wzmocnienia administracji rządowej. Efektem tego było Rozporządzenie Prezydenta Rzeczypospolitej z dnia 19 stycznia 1928 roku o organizacji i zakresie działania władz administracji ogólnej ${ }^{62}$, w którym zamieszczona została „zasada domniemania kompetencji organów administracji rządowej polegająca na działaniu organów samorządowych tylko w sprawach wyraźnie im przekazanych"63.

\section{Scalenie (etap II — lata 1933-1939)}

Dopiero Ustawą z dnia 23 marca 1933 roku o częściowej zmianie ustroju samorządu terytorialnego ${ }^{64}$ (zwaną ustawą scaleniową) wprowadzone zostały jednolite przepisy normujące status i strukturę samorządu gminnego i powiatowego na terenie całego państwa z wyjątkiem województwa śląskiego. Prawodawca zdecydował się na wprowadzenie jednolitego modelu gminy — gminy zbiorowej (wzorem tych istniejących na ziemiach byłego zaboru rosyjskiego), które - o ile

61 Wskazać należy, że w wyborach samorządowych w 1927 r. w Galicji Wschodniej do rad gminnych Ukraińcy zdobyli 56,8\% mandatów, Polacy — 35,2\%; do rad miejskich: Polacy — 43,5\% Żydzi — 36,9\% i Ukraińcy - 18,9\%; a do sejmików powiatowych: Polacy — 67,5\%, Ukraińcy 23,9\% i Żydzi - 7,2\%. Wyniki te odzwierciedlają mieszany skład ludnościowy tych terenów.

62 Dz.U. z 1928 r. Nr 11, poz. 86.

63 H. Izdebski, Samorzad terytorialny w II Rzeczypospolitej, [w:] Samorzad terytorialny. Zagadnienia prawne i administracyjne, red. A. Piekara, Z. Niewiadomski, Warszawa 1998.

${ }^{64}$ Dz.U. z 1933 r. Nr 35, poz. 294. 
nie stanowiły jednej miejscowości — dzieliły się na gromady obejmujące poszczególne miejscowości (osiedla, wsie, sioła, kolonie, osady, miasteczka, zaścianki, folwarki itp. — rozdział 3 ustawy) ${ }^{65}$. Wprowadzony został także podział na gminy wiejskie i miejskie oraz możliwość tworzenia gmin uzdrowiskowych o charakterze użyteczności publicznej (rozdział 7 ustawy). Utrzymano również podział na zadania własne i zlecone. Organem stanowiącym i kontrolnym w gminie była rada gminna, która w miastach nosiła miano rady miejskiej. Rada gminna mogła powoływać stałe, czasowe albo do poszczególnych spraw komisje spośród członków rady (art. 45). Przykładem takiej stałej komisji była komisja rewizyjna (art. 62). Natomiast organem zarządzającym i wykonawczym był zarząd gminny na czele $\mathrm{z}$ wójtem (w miastach zarząd miejski na czele z prezydentem lub burmistrzem art. 1). Zarząd gminy wiejskiej jako organ kolegialny składał się z wójta, podwójciego oraz 2 lub 3 ławników (w gminach liczących ponad 10 tys. mieszkańców). Zarząd miejski (magistrat) składał się z burmistrza i wiceburmistrza (bądź prezydenta i wiceprezydenta ${ }^{66}$ ) oraz odpowiedniej liczby ławników (odpowiadającej $10 \%$ ustawowej liczby radnych — art. 37). Ustawa określała kompetencje organów gminy (rady i zarządu - art. 43 i 44). W odniesieniu do rady były to m.in. powołanie organu zarządzającego i kontrola jego działalności, stanowienie o dobrowolnym podejmowaniu zadań o charakterze publicznym, uchwalanie regulaminów obrad rady i jej komisji czy też uchwał w sprawach majątkowych.

Po unifikacji samorządu terytorialnego dokonanej przez ustawę scaleniową funkcje organów samorządu powiatowego pełniły: rada powiatowa jako organ stanowiący i kontrolny oraz wydział powiatowy jako organ wykonawczy, a ich pracą kierował starosta. Radę powiatową tworzyli radni i członkowie wydziału powiatowego. (art. 1 ust. 1-2, art. 56, art. 57 ust. 5). Radnych rady powiatowej wybierały kolegia wyborcze złożone z radnych i członków zarządów gmin wiejskich i miast niewydzielonych z powiatowych związków samorządowych.

Czynne prawo wyborcze przyznano każdemu mieszkańcowi danej jednostki samorządowej, który zamieszkiwał w niej przynajmniej od roku, licząc wstecz od dnia zarządzenia wyborów, posiadał obywatelstwo polskie oraz ukończył 24 lata. Natomiast bierne prawo wyborcze przysługiwało osobom, które ukończyły do dnia zarządzenia wyborów 30 lat z tym, że na szereg funkcji: burmistrza i jego zastępcy, radnego rady miejskiej i powiatowej, ławnika miejskiego oraz członka wydziału powiatowego mogły zostać wybrane jedynie osoby, które „władają językiem polskim w słowie i piśmie" (art. 3).

65 Stanowiły one swego rodzaju jednostki pomocnicze gminy. Zob. E.Ochendowski, op. cit., s. 285. Organem stanowiącym w gromadzie była rada gromadzka (w miejscowościach liczących ponad 200 mieszkańców) albo zebranie gromadzkie, a organem wykonawczym gromady był sołtys bądź jego zastępca (podsołtys).

$66 \mathrm{~W}$ miastach liczących powyżej 50 tys. mieszkańców rada miejska mogła powziąć uchwałę o powiększeniu liczby wiceprezydentów, z tym że w Warszawie nie mogła ona przekraczać 5, w Krakowie, Lwowie, Łodzi, Poznaniu i Wilnie 3, w innych miastach 2 lub wyjątkowo 3. 
Kadencja organów stanowiących oraz wykonawczych organów samorządu gminnego i powiatowego wynosiła 5 lat ${ }^{67}$. Wyjątkowo zawodowi członkowie zarządu gminy wybierani byli na 10 lat. Co istotne, w miastach wydzielonych z powiatowego związku samorządowego mogli być powoływani tylko zawodowi prezydenci miast i zawodowi wiceprezydenci (art. 2 oraz art. 49 i nast.). Taki członek zawodowy musiał spełniać określone wymagania np. wiek, zamieszkanie w obszarze wyborczym, posiadanie prawa wybieralności (art. 3) oraz posiadać stosowne kwalifikacje, które określał Minister Spraw Wewnętrznych (art. 19). Co istotne, skuteczne dokonanie wyboru ,przełożonego gminy" i jego zastępcy wymagało zatwierdzenia przez odpowiedni organ władzy (np. starostę powiatowego, wojewodę lub Radę Ministrów w stosunku do prezydenta m.st. Warszawy). Odmówienie zatwierdzenia było jednoznaczne z przeprowadzeniem nowych wyborów (art. 50). Niewątpliwie był to sposób oddziaływania na gminę (w zakresie kształtowania jej władz), a tym samym owo zatwierdzanie stanowiło swego rodzaju środek nadzoru. Do innych środków nadzoru zaliczyć należy: zatwierdzanie uchwał, stwierdzenie nieważności z mocy prawa postanowień organów ustrojowych gminy powziętych z naruszeniem istotnych wymagań formalnych albo sprzecznych z prawem, wstrzymanie wykonania uchwały, inspekcje lub rewizje, wgląd w dokumenty oraz delegowanie przedstawicieli władz nadzorczych na posiedzenie organów gmin i utworzonych przez nie komisji (art. 65 i nast.). Niewątpliwie były to istotne instrumenty prawne pozwalające na władczą ingerencję w działania gmin, a więc w ich samodzielność. Regulacje te, ograniczając zadania samorządu terytorialnego, były przejawem występującej po zamachu majowym tendencji do wzmacniania administracji rządowej kosztem uprawnień samorządu, sukcesywnego włączania go do aparatu państwowego ${ }^{68}$ oraz ograniczania jego samodzielności69.

\section{Regulacje konstytucyjne}

Istotnym wsparciem dla ugruntowania samorządu terytorialnego było uchwalenie Konstytucji Rzeczypospolitej Polskiej z 17 marca 1921 roku $^{70}$. Już w art. 3 dokument ten stanowił, że Rzeczpospolita Polska, opierając swój ustrój na zasadzie szerokiego samorządu terytorialnego, przekaże przedstawicielom samorządu właściwy zakres ustawodawstwa, zwłaszcza z dziedziny administracji, kultury

67 W przypadku powołania radnego lub ławnika z tzw. listy zastępców lub w wyniku wyborów uzupełniających pełnił on swoją funkcję do końca kadencji.

68 Zob szerzej C. Burek, Status prawny wójta w samorządzie gminy wiejskiej II RP, „Samorząd Terytorialny" 2008, nr 3, s. 55-56.

69 I. Lipowicz, Samodzielność samorządu terytorialnego w świetle konstytucji, „Przegląd Sejmowy" 2007, nr 4, s. 180.

70 Dz.U. z 1921 r. Nr 44, poz. 267. 
i gospodarstwa - co miało nastąpić w drodze ustaw. Dla celów administracyjnych przyjmowano trójszczeblowy podział państwa na województwa, powiaty i gminy miejskie i wiejskie, które miał być równocześnie jednostkami samorządu terytorialnego. Te jednostki samorządowe mogły się również łączyć w związki dla przeprowadzenia zadań, wchodzących w zakres samorządu, z tym że charakter publiczno-prawny mogły one otrzymywać tylko na podstawie osobnej ustawy (art. 65). Konstytucja przyznawała samorządowi terytorialnemu prawo stanowienia o sprawach mieszczących się w obszarze jego działania, a szczegółowe decyzje w tym zakresie miały podejmować „rady obieralne” — co przesądzało o kolegialnym składzie organu uchwałodawczego oraz wyłanianiu jego członków w drodze wyborów ${ }^{71}$. Co istotne, czynności wykonawcze samorządu wojewódzkiego i powiatowego miały należeć do organów utworzonych na zasadzie zespolenia kolegiów, obieranych przez ciała reprezentacyjne, z przedstawicielami państwowych władz administracyjnych i pod ich przewodnictwem (art. 67). Konstytucja wprowadzała także finansową gwarancję samorządności gmin poprzez rozgraniczenie źródeł dochodów samorządu od dochodów państwa (art. 69). Wreszcie państwo miało sprawować nadzór nad działalnością samorządu przez wydziały samorządu wyższego stopnia. Nadzór ten mógł być jednak częściowo w drodze ustawy przekazany sądownictwu administracyjnemu. Natomiast wyjątkowe przypadki, w których uchwały organów samorządu wymagałyby zatwierdzenia przez organy samorządu wyższego stopnia lub przez ministerstwa, miały być określone ustawami ${ }^{72}$. Przyjęte przez konstytucję marcową rozwiązania i docelowe standardy modelu samorządu terytorialnego pozostawały jednak czysto teoretyczne bez wprowadzenia szczegółowych uregulowań ustawowych.

Stało się to widoczne po zamachu majowym, gdy celem wzmocnienia władzy centralnej podjęto pewne działania zmierzające do ograniczenia samodzielności samorządu terytorialnego. Wprowadzono np. obowiązek zatwierdzania przez władze państwowe osób wybranych na stanowiska samorządowe oraz możliwość powtórzenia wyborów samorządowych w sytuacji braku akceptacji przez organy nadzoru osób wybranych na stanowiska wójta lub sołtysa ${ }^{73}$.

Natomiast Ustawa konstytucyjna z dnia 23 kwietnia 1935 roku $^{74}$ kwestię samorządu terytorialnego regulowała w sposób niezwykle lakoniczny. Wskazywa-

71 Przyjęcie takiej regulacji potwierdzało korporacyjny charakter jednostek samorządu terytorialnego i ich prawo do samodzielnego decydowania o ich sprawach. Zob. B. Dolnicki, Samorzad terytorialny, Warszawa 2012, s. 49.

72 Ryszard Szwed ocenił, że konstytucja marcowa zawierała postępowe poglądy dotyczące istoty i roli samorządu terytorialnego. Wyznaczyła mu niezwykle rozległy zakres działania, zapewniając także znaczną samodzielność prawną względem państwa. R. Szwed, Samorząd terytorialny w drugiej Rzeczypospolitej (1918-1939). Zarys problematyki, [w:] Samorzadowa Rzeczypospolita 1918-1939. Wybór rozpraw i artykułów, Częstochowa 2002, s. 15.

73 Por. § 9 Rozporządzenia Ministra Spraw Wewnętrznych z dnia 25 maja 1927 r. o regulaminie wyborczym rad gminnych w gminach wiejskich na obszarze b. Królestwa Kongresowego.

74 Dz.U. Nr 30, poz. 227. 
ła ona, że państwo powoła samorząd terytorialny „do udziału w wykonywaniu zadań życia zbiorowego" (art. 4). Administracja państwowa, którą uznawano za służbę publiczną, była sprawowana m.in. przez samorząd terytorialny (art. 72). $\mathrm{W}$ art. 73 konstytucja kwietniowa wprowadzała podział terytorium państwa dla celów administracyjnych na: województwa, powiaty oraz gminy miejskie i wiejskie. Usankcjonowano zatem dotychczasowy (dychotomiczny) podział gmin na wiejskie i miejskie. Gminy miejskie mogły ponadto tworzyć większe jednostki powiaty lub województwa grodzkie. Wreszcie w art. 75 wskazano, że samorząd wojewódzki, powiatowy i gminny powołuje się w celu urzeczywistniania zadań administracji państwowej w zakresie potrzeb miejscowych. Samorządy miały prawo w zakresie ustalonym ustawą na obszarze swojego działania wydawać normy powszechnie obowiązujące pod warunkiem ich uprzedniego zatwierdzenia przez organ (,władzę") nadzoru. Nadto mogły być łączone w związki dla wykonywania zadań szczególnych. Co ciekawe, konstytucja kwietniowa nie przyznawała samorządowy terytorialnemu osobowości publiczno-prawnej, ta mogła być nadana drogą odrębnej ustawy. Przyjęte w konstytucji kwietniowej skromne regulacje dotyczące samorządu terytorialnego były przejawem zmiany idei samorządu przez odmienne postrzeganie jego istoty, funkcji oraz roli sprawowanej w państwie. I chociaż samorząd nie stanowił już odrębnego, niezależnego od państwa bytu, to jednak nadal uznawano jego szczególne miejsce w ramach organizacji państwa, które teraz samo organizowało społeczeństwo w struktury samorządowe ${ }^{75}$.

\section{Podsumowanie}

Biorąc pod uwagę całokształt okoliczności zewnętrznych i wewnętrznych, należy w pełni docenić proces kształtowania struktur samorządu terytorialnego w odrodzonej Polsce. Niewątpliwie zasadnym było przyjęcie na początkowym etapie tworzenia zrębów struktury organizacyjnej powstającego państwa ewolucyjnej, a nie rewolucyjnej metody ich budowania. Zdawano sobie sprawę, że przezwyciężanie granic rozbiorów wymagało będzie zmian prawno-ustrojowych oraz społeczno-gospodarczych. Było to także adekwatne do ówczesnego poziomu rozwoju cywilizacyjnego, kultury prawnej społeczeństwa, stopnia przygotowania elit politycznych (także pod względem koncepcyjnym modelu samorządu terytorialnego, wizji jego miejsca i roli w państwie) oraz samego aparatu państwowego. Wydaje się, że pewien chaos terminologiczny i spadek sprawności administracji samorządowej wynikający z pozostawienia z pewnymi niezbędnymi modyfikacjami dotychczasowych struktur samorządowych opartych na różnych regulacjach

75 L. Górnicki, Idea samorządu w konstytucji kwietniowej z 1935 r., [w:] Samorząd i samorządność w przeszłości i teraźniejszości, red. M.J. Ptak, Wrocław 2013, s. 125-134. 
normatywnych państw zaborczych (które jednak już funkcjonowały oraz były znane i zrozumiałe dla mieszkańców) był lepszy niż ewentualny chaos spowodowany budowaniem całkowicie nowych struktur organizacyjnych samorządu. Uświadomić sobie należy, iż odbywałoby się to w warunkach wojny, późniejszego kryzysu gospodarczego, silnych wewnętrznych konfliktów politycznych ${ }^{76}$ (tak w ujęciu kryzysu parlamentaryzmu, częstych zmian rządu, jak i w konsekwencji zamachu majowego), jak również kształtowania się rozumienia samorządu terytorialnego ${ }^{77}$, nie mówiąc już o samym docelowym modelu struktury samorządu terytorialnego ${ }^{78}$. Stąd też zmiany prawodawcze stanowiące odpowiedź na pojawiające się faktycznie potrzeby, ale i realizujące polityczne koncepcje sprawowania władzy. I choć oczywiście ustawę scalającą z 1933 roku należy ocenić pozytywnie, jako krok pozwalający na ujednolicenie w skali państwa struktury samorządu terytorialnego i realizujący konsekwentnie pewien jego model, to nie była ona wolna od wad, tak w ujęciu samorządu na szczeblu powiatu, jak i roli samorządu terytorialnego w państwie ${ }^{79}$. Nie udało się dokończyć do wybuchu II wojny światowej tworzenia struktur samorządu terytorialnego na szczeblu wojewódzkim. Brak było nawet realnej koncepcji funkcjonowania w sposób jednolity samorządu na tym szczeblu. Niemniej docenić należy wysiłek zmierzający do zniwelowania rozbieżności prawnych i stojących za nimi różnic ekonomicznych, kulturowych (w tym poziomu wykształcenia i analfabetyzmu), populacyjnych i narodowościowych. Jak wielki był to trud i ogrom kwestii polityczno-prawnych możemy sobie uzmysłowić, kiedy nawet wzbogaceni późniejszym doświadczeniem własnym i innych państw podjęliśmy w 1989 roku działania zmierzające do przywróce-

76 Zob. R. Szwed, Samorzad terytorialny w Polsce w latach 1918-1939. Wybór materiatów źródtowych, Częstochowa 2000; R. Chwedoruk, Polskie tradycje samorząowe. Samorząd terytorialny w polskiej myśli politycznej. Część 1, „Społeczeństwo i Polityka” 2006, nr 1, s. 9 n.; R. Stawicki, Samorzad terytorialny w II Rzeczypospolitej - zarys prawno-historyczny, Opracowania tematyczne OT-638, Warszawa 2015, s. 15 n.

77 Widoczne było ścieranie się koncepcji naturalistycznej samorządu jako podmiotu pierwotnego i niezależnego od państwa (jej zwolennikami byli m.in. A. Kroński, T. Bigo i legła ona u podstaw ujęcia samorządu terytorialnego w konstytucji marcowej) oraz koncepcji państwowej upatrującej funkcjonowanie samorządu w woli państwa, które powołuje samorząd do wykonywania jego zadań i tym samym określa prawa i obowiązki samorządu terytorialnego (samorząd jest podmiotem wtórnym wobec państwa, zwolennikami tej teorii byli J. Panejko, K. Kumaniecki, W. Jaworski). Zob. A. Bosiacki, op. cit.

78 W pewnym uogólnieniu: koncepcja prawicowa opowiadała się za silną centralizacją administracji publicznej i samorządem wpisanym w taki układ organizacyjny, natomiast koncepcja lewicowa zakładała tworzenie samorządu terytorialnego o szerokiej samodzielności poszczególnych jego jednostek. Zob. M. Sidor, Samorząd terytorialny w myśli politycznej II Rzeczypospolitej, Toruń 2010.

79 Już z uzasadnienia projektu tej ustawy wynikało, że ,,projekt rządowy zrywa z liberalną doktryną odrębności administracji rządowej i samorządowej i staje na stanowisku, iż samorząd terytorialny jest jedynie przedłużeniem i uzupełnieniem administracji rządowej, że do pewnego stopnia jest instytucją zastępczą, pomocniczą w stosunku do administracji państwowej." — podaję za: R. Stawicki, op. cit., s. 14. 
nia i utrwalenia samorządu terytorialnego w Polsce. Na wspomnienie zasługuje także znaczący dorobek polskiej doktryny okresu międzywojennego w badaniu samorządu terytorialnego, by wspomnieć tylko Tadeusza Bigo ${ }^{80}$, Henryka Dembińskiego $^{81}$, Maurycego Jaroszyńskiego ${ }^{82}$, Władysława Leopolda Jaworskiego ${ }^{83}$, Aleksandra Krońskiego ${ }^{84}$, Kazimierza Władysława Kumanieckiego ${ }^{85}$, Jerzego Panejkę $^{86}$, Szczęsnego Wachholza ${ }^{87}$ i Bohdana Wasiutyńskiego ${ }^{88}$ oraz rozwój czasopism poświęconych tej tematyce m.in. „Samorządu Terytorialnego” oraz „Samorządu Miejskiego”.

\section{Bibliografia}

Adamczyk M., Pietruszka S., Konstytucje polskie w rozwoju dziejowym 1791-1982, Warszawa 1985. Bosiacki A., Od naturalizmu do etatyzmu. Doktryny samorządu terytorialnego Drugiej Rzeczypospolitej 1918-1939, Warszawa 2006.

Bukowski Z., Jędrzejewski T., Rączka P., Ustrój samorządu terytorialnego, Toruń 2013.

Burek C., Status prawny wójta w samorządzie gminy wiejskiej II RP, „Samorząd Terytorialny” 2008, nr 3.

Chojnowski A., Koncepcje polityki narodowościowej rządów polskich w latach 1921-1939, Wroclaw 1979.

Chwedoruk R., Polskie tradycje samorządowe. Samorząd terytorialny w polskiej myśli politycznej. Część 1, „Społeczeństwo i Polityka” 2006, nr 1.

Dolnicki B., Samorząd terytorialny, Warszawa 2012.

Dziki T., Administracja gmin wiejskich w Królestwie Polskim w latach 1815-1864, „Klio” 2015, nr 1. Filipek J., Prawo administracyjne — instytucje ogólne. Czesść 1, Zakamycze 2003.

Folejewski J., Wróblewski T., O samorządzie ziemskim na Litwie i Białejrusi, Wilno 1910.

Gałędek M., Odrębności ustroju samorządu terytorialnego na ziemi wileńskiej w okresie międzywojennym, „Z Problemów Administracji. Administracja Publiczna” 2010, nr 2/1a, red. T. Maciejewski, J. Gierszewski.

80 T. Bigo, Zwiazki publiczno-prawne w świetle ustawodawstwa polskiego, Warszawa 1928; idem, Z ustrojowych zagadnień samorząu, Lwów 1933.

81 H. Dembiński, Osobowość publiczno-prawna samorzadu w świetle metody dogmatycznej i socjologicznej, Wilno 1934.

82 M. Jaroszyński, Stosunek samorzadu gminnego do powiatowego, Warszawa 1921; idem, Samorzad terytorialny w Polsce. Stan obecny. Wnioski do reformy, Warszawa 1923; idem, Samorzad gminy wiejskiej, Warszawa 1925.

83 W.L. Jaworski, Nauka prawa administracyjnego. Zagadnienia ogólne, Warszawa 1924.

84 A. Kroński, Teorja samorzadu terytorialnego, Warszawa 1932.

85 K.W. Kumaniecki, Ustrój władz samorządowych na ziemiach Polskich w zarysie, Warszawa-Kraków 1921; idem, Centralizm i decentralizacja, „Ruch Prawniczy, Ekonomiczny i Socjologiczny" 1922, s. 232-233.

86 J. Panejka, Geneza i podstawy samorzadu terytorialnego, Wilno 1934.

87 S. Wachholz, Nowy ustrój samorządu terytorialnego w Polsce i jego wartości, Kraków 1934.

88 B. Wasiutyński, Ustrój władz administracyjnych rządowych i samorządowych, Poznań 1937; idem, Centralizm a samorzą, „Przegląd Narodowy” 1921, R. 10, nr 2. 
Górnicki L., Idea samorzadu w konstytucji kwietniowej z 1935 r., [w:] Samorząd i samorzadność w przeszłości i teraźniejszości, red. M.J. Ptak, Wrocław 2013.

Izdebski H., Historia administracji, Warszawa 1997.

Izdebski H., Samorząd terytorialny w II Rzeczypospolitej, [w:] Samorząd terytorialny. Zagadnienia prawne i administracyjne, red. A. Piekara, Z. Niewiadomski, Warszawa 1998.

Kołaczkowski B., Ratajczak M., Wpływ odzyskania niepodległości na kształt i zakres samodzielności władz samorzadu terytorialnego na ziemiach byłego zaboru rosyjskiego, „Studia Prawa Publicznego" 2013, nr 3.

Kroński A., Teorja samorządu terytorialnego, Warszawa 1932.

Kutrzeba S., Historya ustroju Polski w zarysie, t. 3, Lwów 1920.

Lipowicz I., Samodzielność samorządu terytorialnego w świetle konstytucji, „Przegląd Sejmowy” $2007, \mathrm{nr} 4$.

Lipowicz I., Tradycje i przyszłość samorzadu terytorialnego w świetle nauki prawa administracyjnego, [w:] Między tradycją a przyszłością w nauce prawa administracyjnego. Księga jubileuszowa dedykowana Profesorowi Janowi Bociowi, red. J. Supernat, Wrocław 2009.

Maciejewski T., Samorząd terytorialny II Rzeczypospolitej (1918-1939), „Z Problemów Administracji. Administracja Publiczna” 2010, nr 2/1a, red. T. Maciejewski, J. Gierszewski.

Ochendowski E., Prawo administracyjne. Część ogólna, Toruń 2001.

Pazdro Z., Przemiany ustrojowe samorządu terytorialnego na obszarze bytej Galicji (1918-1939), Lwów 1939.

Pragier A., Zarys skarbowości komunalnej, cz. 1, Warszawa 1924.

Sidor M., Samorzą terytorialny w myśli politycznej II Rzeczypospolitej, Toruń 2010.

Starościak J., Decentralizacja administracji, Warszawa 1960.

Stawicki R., Samorzad terytorialny w II Rzeczypospolitej - zarys prawno-historyczny, Opracowania tematyczne OT-638, Warszawa 2015.

Szwed R., Samorzad terytorialny w drugiej Rzeczypospolitej (1918-1939). Zarys problematyki, [w:] Samorządowa Rzeczypospolita 1918-1939. Wybór rozpraw i artykułów, Częstochowa 2002.

Szwed R., Samorząd terytorialny w Polsce w latach 1918-1939. Wybór materiałów źródłowych, Częstochowa 2000.

Szwed R., Samorzadowa Rzeczpospolita 1918-1939, Częstochowa 2000.

Tomczyk R., Od namiestnika do wojewody. Likwidacja zaborczego systemu prawno-administracyjnego w Galicji w okresie budowy II Rzeczypospolitej (1918-1921). Wybrane zagadnienia, „Zeszyty Naukowe Uniwersytetu Rzeszowskiego” 2010, nr 64.

Wasiutyński B., Ustrój władz administracyjnych rządowych i samorządowych, Poznań 1937.

Witkowski W., Historia administracji w Polsce 1764-1989, Warszawa 2007.

Wójcik S., Samorząd terytorialny w Polsce w XX wieku. Myśl samorzadowa: historia i współczesność, Lublin 1999.

Wrabec D., Tymczasowy Wydziat Samorządowy, Lwów 1933.

\title{
Territorial self-government in the interwar period
}

\author{
Summary
}

Among the challenges of the resurgent Polish state in 1918 was also the construction of its own public administration structure. By taking over the partitioning countries' different models of administration and territorial self-government (with diversified structure and stage of development), it was advisable to adopt an evolutionary method of creating its organizational structure. Therefore, it 
was based on the existing structures, well-known to local people, modifying them only towards democratization, levelling out differences and achieving certain desirable standards. Therefore, two basic stages in the construction of the territorial self-government of the Second Polish Republic can be distinguished: first, to cause the consolidation act to enter into force and the second subsequent one. And although the merger law of 1933 should be assessed positively as a step allowing for the unification of the territorial self-government structure at the level of the commune (gmina) and district (powiat) on a national scale, it was not free from defects. The territorial self-government structures at the provincial level had not been fully established. This was partly due to the lack of a coherent concept of the functioning of local self-government, its place in public administration and its role in the state. The striving for the centralization of the state apparatus (after 1926) was visible not only in statutory amendments, but also in laconic regulations of the April constitution concerning local self-government. However, the effort to overcome legal disparities and the economic, cultural, population and national differences that was put into unifying and building the territorial self-government structures in 1918-1939 should be fully appreciated. The significant achievements of the Polish doctrine of the interwar period in the study of territorial self-government and the development of magazines devoted to this subject should also be mentioned.

Keywords: territorial self-government, interwar period, Second Polish Republic. 